\title{
Research in older adult health: investments in the last ten years
}

Over the last ten years Brazil has maintained its level of investment in research and development (R\&D) at approximately 1\% of its gross domestic product (GDP). With the 2016-2022 Action Plan for Science, Technology and Innovation (or Pacti), total investment increased to $1.23 \%$ of GDP, an increase which is still far from the average percentage (2.3\%) invested by Organization for Cooperation and Economic Development (OECD) countries ${ }^{1}$. In order to achieve this target, increased investments will be required in the coming years, so that the expenditure on $\mathrm{R} \& \mathrm{D}$, as well as on the human resources involved, remains relevant.

In Brazil, historically, the most significant funding source for R\&D has been the government. The Ministry of Health (MH) became an important financial backer, inducer and user of health research ${ }^{2}$ when it assumed the responsibility of leading the management of science, technology and innovation in health a role delegated to the National Health System (or SUS) in article 200, item V, of the Federal Constitution of $1988(\mathrm{CF} / 88)^{3}$.

In this context, in 2004, two important institutional frameworks for scientific and technological development in health in Brazil were launched - the National Policy on Science, Technology and Innovation in Health (or PNCTIS) ${ }^{2}$ and the National Agenda for Health Research Priorities (or ANPPS) ${ }^{4}$, considered to be guiding tools for the fostering of actions promoted by the $\mathrm{MH}$.

Resources for funding most health research come from the bilateral cooperation fund of the Ministry of Science, Technology and Innovation (MSTI) and the $\mathrm{MH}^{5}$. National research is financed with technical and administrative support from the National Council for Scientific and Technological Development (or CNPq), the Funding of Studies and Projects body (or Finep) or the SUS Shared Health Management Research Program (or PPSUS).

When analyzing the sub-agenda for the health of older adults, in the period from 2010 to 2019, investment was approximately $\mathrm{R} \$ 100$ million, which supported 6,822 scientific, technological and innovation research projects in the area of older adult health. Of these, 6,760 projects were contracted via CNPq Public Notices and Calls, allocating a total of $\mathrm{R} \$ 79.8$ million, while in the $\mathrm{MH}$ the investment was $\mathrm{R} \$ 19.6$ million distributed in the following modalities: a) National Fostering, with the amount of $\mathrm{R} \$ 0.78$ million allocated for four research projects; b) PPSUS, which allocated $\mathrm{R} \$ 4.8$ million among 55 surveys, and c) direct contracting, with a total of $\mathrm{R} \$ 14.1$ million for the contracting of three surveys.

The distribution of research by period revealed that while productivity increased over the entire period, in 2017, there was a significant contribution of resources for research, around $\mathrm{R} \$ 20.2$ million. 
Two regions exhibited the greatest productivity: the southeast with 3,673 studies and an investment of $\mathrm{R} \$ 52$ million and the south with 1,537 studies and an investment of R \$14.2 million, with emphasis on São Paulo and Rio Grande do Sul, the states with the greater number of research groups in the area of aging ${ }^{6}$.

The major areas of knowledge with the greatest concentration of resources and research were the biological sciences ( $\mathrm{R} \$ 53$ million and 3,013 studies) and health sciences ( $\mathrm{R} \$ 26.9$ million and 3,681 studies). This may be the result of the predominance of research focusing on the aging process of the Brazilian population carried out in the area of health sciences, with the significant participation of biological sciences ${ }^{6}$.

Currently, several initiatives in favor of healthy, active aging with a good quality of life are being prioritized through the implementation of public policies in line with Sustainable Development Goals (SDGs) ${ }^{7}$, associated with the financing of scientific and technological research.

While advances have been observed through the results of studies and research, there are still gaps that require new scientific, technological and innovation knowledge, that will provide further scientific evidence and contribute to the improvement of public policies, programs, services and technologies focused on the health of older adults in Brazil.

Brazil possesses a significant critical mass and capacity of expertise in the area of research in older adult health. However, greater investment in this area is required, generating knowledge that brings answers and solutions to the priority health problems of the older population.

Luci Fabiane Scheffer Moraes

Consultora técnica no Ministério da Saúde, pós-doutoranda no Programa de Saúde Coletiva da Universidade de Brasília (UnB). Distrito Federal, Brasília, Brasil.

Gilberto Ferreira de Souza

Analista em Ciência em Tecnologia - Sênior do CNPq, doutor em Educação em Ciência pela Universidade Federal do Rio Grande do Sul (UFRGS). Porto Alegre, Rio Grande do Sul, Brasil.

\section{REFERENCES}

1. Brasil. Ministério da Ciência, Tecnologia, Inovações e Comunicações. Estratégia Nacional para Ciência, Tecnologia e Inovação 2016-2022: sumário executivo. Brasília, DF: CTIDES; 2016.

2. Brasil. Ministério da Saúde, Secretaria de Ciência Tecnologia e Insumos Estratégicos, Departamento de Ciência e Tecnologia. Política Nacional de Ciência Tecnologia e Inovação em Saúde. $2^{a}$ ed. Brasília, DF: MS; 2008.

3. Brasil. Constituição 1988. Constituição da República Federativa do Brasil. Brasília, DF: Senado Federal; 1988.

4. Brasil. Ministério da Saúde, Secretaria de Ciência, Tecnologia e Insumos Estratégicos. Departamento de Ciência e Tecnologia. Agenda Nacional de Prioridade em Pesquisa em Saúde. $2^{a}$ ed. Brasília, DF: MS; 2008.

5. Brasil. Portal Saúde [Internet]. Brasília, DF: Ministério da Saúde, 2011 [acesso em 15 out. 2011]. Disponível em: http://portal.saude.gov.br/portal/saude/Gestor/area.cfm?id_area=1504

6. Prado DS, Sayd JD. A pesquisa sobre envelhecimento humano no Brasil: grupos e linhas de pesquisa. Ciênc Saúde Colet. 2004;9(1):57-68.

7. Organização das Nações Unidas. Report of the Open Working Group of the General Assembly on Susteinable Development Goals. UN Report A/68/970: 2014 [Internet]. New York: ONU; 2014 [acesso 08 jul. 2015]. Disponível em: http://www.un.org/en/development/desa/news/sustainable/sdgs-post2015.html 